DOI https://doi.org/10.32782/2305-9389/2020.23.22

УДК 351

Гребенюк Богдан, аспірант кафедри публічного управління та менеджменту інноваційної діяльності Навчально-наукового інституту післядипломної освіти Національного університету біоресурсів та природокористування України

\title{
ІНДЕКС СПРИЙНЯТТЯ КОРУПЦІї
}

\begin{abstract}
Статтю присвячено аналізу особливостей індексу сприйняття корупиії. Складність вивчення корупції як явища в суспільстві полягає в тому, щьо вона має глибоко латентний характер. Неможливо вивчити корупцію на основі тільки статистичних даних: по-перше, офіційна статистика не повною мірою відображає справжній стан справ; по-друге, такі дані будуть характеризувати насамперед якість роботи правоохоронних органів або ЗМІ з виявлення фактів корупиії; по-третє, статистичні дані дають нам уявлення не про корупцію, а про корупиійну злочинність, і поняття ичі не тотожні. У статті пояснюється, щ⿻о спроби дослідників створити універсальну методику, засновану на математичних обчисленнях, важко виконати. Це пояснюється тим, щцо корупційні прояви, по-перше, не можуть бути достовірно виміряні, по-друге, мають кількісні (стан і динаміка) i якісні (структура і характер) характеристики, $і$ неможливо перевести иі якісні характеристики в ичифровий вираз. Індексу сприйняття корупиії властива певна частка похибки через те, щяо він заснований на опитуванні людей, навіть авторитетних і досвідчених. Люди намагаються бути об'єктивними, але насправді це важке для них завдання. У статті робиться висновок, щзо нині доводиться констатувати, щзо, на жаль, немає джерел інформачії про корупчію, які задовольняли б вимогу міжкраїнної порівнянності. Індекс сприйняття корупції не може використовуватися як абсолютно точний інструмент аналізу і порівняння, бо він розраховується на базі мінливого набору джерел даних: змінювалася кількість джерел даних $і$ країн, щзо включаються в індекс; з'являлися нові опитування, а проведення деяких досліджень припинялося. Крім того, в методологію розрахунку Індексу сприйняття корупиї вносилися зміни. Тому єдиним надійним способом порівняння є зіставлення даних по певній державі з одного і того самого конкретного джерела протягом певного періоду часу.
\end{abstract}

Ключові слова: корупція, протидія корупиії, корупиійні порушення, індекс сприйняття корупиії.

\section{Hrebeniuk Bohdan. Corruption perception index}

The article is devoted to the analysis of the features of the Corruption Perception Index. The difficulty of studying corruption as a phenomenon in society lies in the fact that it is deeply latent. It is impossible to study corruption on the basis of statistics alone: firstly, official statistics do not fully reflect the true state of affairs; secondly, such data will characterize first of all the quality of work of law enforcement agencies or the media to identify facts of corruption; thirdly, statistics give us an idea not of corruption, but of corruption crime, and these concepts are not identical. The article explains that researchers' attempts to create a universal methodology based on mathematical calculations are difficult to implement. This is explained by the fact that corruption manifestations, firstly, cannot be reliably measured; secondly, they have quantitative (state and dynamics) and qualitative (structure and nature) characteristics, and it is impossible to translate these qualitative characteristics into digital expression. The Corruption Perception Index has a certain margin of error due to the fact that it is based on a survey of people, even reputable and experienced ones. People try to be objective, but in reality this is a difficult task for them. The article concludes that today it is necessary to state the fact that, unfortunately, there are no sources of information about corruption that would satisfy the requirement of inter-country comparability. The Corruption Perception Index cannot be used as an absolutely accurate analysis and comparison tool, as it is calculated on the basis of a changing set of data sources: the number of data sources and countries included in the index changed; new surveys appeared, and some studies were discontinued. Moreover, changes were made to the methodology for calculating the Corruption Perception Index. Therefore, the only reliable way to compare is to compare data for a specific state from the same specific source over a certain period of time.

Key words: corruption, anti-corruption, corruption violations, Corruption Perception Index.

Якщо розуміти під корупцією як соціальним явищем не тільки підкуп і хабарництво, а будь-яке зловживання державною владою з метою отримання особистої вигоди [1, с. 53], то можна стверджувати, що, як тільки виник управлінський апарат, суспільство зіткнулося з корупцією. Ще Ш. Монтеск'є писав, що кожна людина, яка володіє владою, схильна зловживати нею, поки не досягне покладеної на неї межі [2, с. 105].

Емпіричні дані дослідження показують, що більш корумповані країни, як правило, мають нижчі рівні розвитку людського потенціалу [3, с. 32]. Крім того, доведено, що високий рівень корумпованості неминуче викликає нерівність у доходах і бідність [4, с. 29]. Д. Кауфман вважає, що однією $з$ основних причин світової фінансової кризи в 2008 р. стала корупція, зокрема лобіювання фінансовими титанами занижених стандартів резервування активів [5]. 
Складність вивчення корупції як явища в суспільстві полягає в тому, що вона має глибоко латентний характер. Неможливо вивчити корупцію на основі тільки статистичних даних: по-перше, офіційна статистика неповною мірою відображає справжній стан справ; по-друге, такі дані будуть характеризувати насамперед якість роботи правоохоронних органів або ЗМІ з виявлення фактів корупції; по-третє, статистичні дані дають нам уявлення не про корупцію, а про корупційну злочинність, і поняття ці не тотожні (корупційна злочинність - це лише частина корупції, хоча і сама суспільно небезпечна).

Корупція була і залишається однією з глобальних проблем сучасності. Немає держав без корупції (хоча Сінгапуру практично вдалося викорінити корупцію як соціальне явище), але їі рівень у країнах істотно різниться. Усі ці фактори дають право говорити про актуальність представленої теми та необхідність постійних моніторингових досліджень корупційних проявів у суспільстві.

Ефективність протидії держав корупції знаходиться у фокусі безлічі досліджень в останні роки. Оцінка ефективності значною мірою ускладнена тим фактом, що залежно від держави, iіi історії, традицій, національного менталітету та культурних особливостей масштаби ії прояву можуть разюче відрізнятися. Усе це також ускладнюється тим, що частота і обсяги корупційних злочинів (правопорушень) можуть відрізнятися залежно від конкретного рівня суспільних відносин (побутова, комерційна, державна і т. п.; багатьом державам вдалося скоротити, наприклад, кількість корупційних злочинів на побутовому рівні або на рівні державних установ 3 обслуговування населення, однак при цьому корупція може процвітати у вищих ешелонах влади). Таким чином, корупція для різних держав різниться істотно, i створення агрегованого індексу, що враховує всю багатоплановість і багатогранність цього феномена, $є$ спробою привести рівень ефективності боротьби з корупцією з боку держав до одного знаменника.

Зокрема, оцінка ефективності протидії держав корупції за допомогою Індексу сприйняття корупції закономірно викликає науковий інтерес дослідників. Водночас очевидно, що при всій багатогранності явища і методів протидії йому автори висловлюють і критичні зауваження. Багато авторів позитивно оцінюють важливість цього індексу для досліджень в області корупції, сприймаючи його як барометр поточного рівня корупції для конкретної держави і світу загалом. Критики, наприклад, О.Г. Савчишкіна [6, с. 145], Н.Б. Капітонова і Н.В. Тумаланов [7, с. 53], вказують на ту обставину, що індекс сприйняття корупції не є універсальним показником. Помилковим інструментом вважає Індекс сприйняття корупцiї Transparency International (CPI) і В. де Марія [8, с. 38], обгрунтовуючи свою думку тією обставиною, що він не враховує культурні відмінності країн і орієнтований тільки на бізнес-клімат.

Протягом останніх років міжнародне співтовариство звернуло пильну увагу на проблему корупції як на міжнародному рівні, так і на національному рівні окремо взятої держави. Корупція в найбільш загальному визначенні означає «зловживання службовим становищем у корисливих цілях» [9, с. 74]. Проблема корупції полягає в тому, що вона порушує права мільйонів людей по всьому світі, має згубну дію на економіку, ускладнює міжнародне співробітництво, створює основу організованої злочинності, $є$ джерелом фінансування терористичних організацій та інших. Для того, щоб викорінити злочинність, необхідне проведення низки реформ, удосконалень законодавчої бази, практики правозастосування. Особливу значимість у боротьбі з корупцією мають результати наукових досліджень, зокрема дані кримінологічних досліджень. Необхідність боротьби з національною, транснаціональною та міжнародною корупцією не піддається сумніву. Саме боротьба, на відміну від протидії або контролю, передбачає повне викорінення, боротьба як процес передбачає остаточну перемогу над цим руйнівним явищем. Для належного розуміння корупції як явища особливого значення набуває вимір рівня корупції та вимір сприйняття корупції. Ці питання не $\epsilon$ однозначно встановленими, і до теперішнього моменту в науковому середовищі не вщухають дискусії на предмет можливості, доцільності, об'єктивності проведення вимірювання корупції.

Щороку 9 грудня вся світова спільнота святкує Міжнародний день боротьби 3 корупцією. Саме в цей день у 2003 р. ООН була прийнята Конвенція проти корупції (UNCAC). Серед безлічі міжнародних організацій, що займаються антикорупційною діяльністю, в цілях дослідження нас цікавлять лише деякі з них, наприклад: «Міжнародна антикорупційна академія, Міжнародна асоціація органів по боротьбі з корупцією, Міжнародний форум представників ділових кіл, незалежна комісія з боротьби 3 корупцією, Трансперенсі Інтернешнл, TRACE International» [10].

Водночас варто зазначити, що діяльність міжнародних антикорупційних організацій викликає неоднозначне ставлення як серед звичайних громадян, так і в ділових і наукових колах. Найгрубішим видається поділ їх на прихильників і противників діяльності міжнародних антикорупційних організацій та їхніх досліджень. Противники таких досліджень, як правило, представляють країни з низьким показником антикорупційного індексу. У наукових джерелах не вдалося зустріти думки про відсутність необхідності створення і функціонування подібних організацій, а скоріше зустрічається критика об'єктивності їхніх досліджень, точності представлених ними індексів, їх неупередженості 
та афілійованості. До принципових варто також зарахувати питання про фактичну можливість проведення вимірювань, пов'язаних із корупцією.

Спроби дослідників створити універсальну методику, засновану на математичних обчисленнях, важко виконати. Це пояснюється тим, що корупційні прояви, по-перше, не можуть бути достовірно виміряні, по-друге, мають кількісні (стан і динаміка) і якісні (структура і характер) характеристики, і неможливо перевести ці якісні характеристики в цифровий вираз. С.В. Поляков називає причини, які ускладнюють оцінку динаміки корупційності країни, регіону або окремої території. На його думку, існує безліч показників, що характеризують корупційність; крім того, важко піддаються обліку всі фактори, що впливають на показники корупції, а також вплив цих факторів різниться як за силою, так і за напрямом [11, с .24].

3 цих причин широкого поширення набули соціологічні дослідження корупції, засновані на опитуваннях і експертних оцінках. Виділяють два їх типи [12, с. 88]:

1) дослідження, в яких корупція є основним об'єктом вивчення (наприклад, дослідження Transparency International також підкреслює культурний аспект відмінностей між державами, М.А. Батищева [13, с. 198]);

2) дослідження, в яких корупція виступає однією зі складових частин «непрозорості» та економічної свободи в окремо взятій державі.

Transparency International - міжнародна некомерційна і неурядова організація, створена в 1993 p. вона займається дослідженнями корупції. Індекс сприйняття корупції (Corruption Perceptions Index, CPI, IBK) розраховується Transparency International з 1995 р. Індекс сприйняття корупції - це щорічний показник, заснований одночасно на соціологічних дослідженнях і оцінках експертів. Він проводиться в понад 175 країнах світу міжнародними організаціями та інститутами, в тому числі Світовим банком, Світовим економічним форумом, азіатським і африканським банками розвитку. Основою при розрахунку Індексу сприйняття корупції стало припущення про те, що поєднання джерел інформації (не менше трьох для кожної країни, включеної в Індекс), об'єднаних в єдиний показник, збільшує його надійність. Щоб оцінити рівень корупції, опитують підприємців та аналітиків (як резидентів, так і іноземців), які проживають у досліджуваній країні. Таким чином, рівень корупції в певній державі оцінюється з різних позицій: громадян країни (погляд «зсередини») та іноземних громадян (погляд «ззовні»). Ранжування країн відбувається за десятибальною шкалою. 10 балів означають відсутність корупції, а 0 балів - дуже високий ії ступінь. Країни оцінюються за чотирма показниками: 1) взаємодія бізнесу з владою; 2) антикорупційне законодавство; 3) громадський контроль і контроль 3МІ (причому, на думку деяких дослідників, засоби масової інформації можуть бути одним із самостійних джерел вимірювання Індексу сприйняття корупції [14, с. 15]); 4) прозорість діяльності держорганів.

За результатами досліджень за 2019 р., представлених агентством Трансперенсі Інтернешнл, боротьба з корупцією перебуває в стані стагнації. Подібне положення характерно для більшості держав. Водночас у багатьох західних країнах і країнах із розвиненою ринковою економікою спостерігається навіть певна динаміка зниження.

Огляд основних результатів Індексу сприйняття корупції (IBК) за 2019 рік задає вектори дослідження певних видів корупції. За результатами цих досліджень можна простежити динаміку змін. Ця динаміка часто залежить від політичної кон'юнктури, зовнішніх і внутрішніх факторів окремих держав. Недивно, що немає держав з індексом 100 або 90 (тобто де немає корупції або вона абсолютно не значна). Це наочно показує, що корупція зачіпає всі без винятку держави. Продемонструємо найяскравіші показники.

1-е місце ділять Нова Зеландія і Данія - по 87 балів. Як і багато інших західних країн, останнім часом вони теж погіршили результати. За нею слідують Фінляндія (86), Швейцарія (85), Швеція (85) і Сінгапур (85 балів). Німеччина посідає 9-е місце, набравши 80 балів. Останнє місце (180) займає Сомалі 39 балами, відразу за Суданом, що має 12 балів. Середнім показником $є$ значення в 43 бали, при цьому без малого три чверті країн не можуть досягти навіть позначки в 50 балів зі 100.

Публікація нового глобального індексу сприйняття корупції супроводжувалася вираженням із боку «Трансперенсі Інтернешнл» заклопотаності щодо останніх тенденцій. Як заявили її представники під час презентації в Берліні, більше двох третин з охоплених дослідженнями 180 країн продемонстрували стагнацію, а то і регрес у своїх зусиллях по боротьбі з корупцією. Німеччина, як і в попередньому році, набрала 80 з 100 можливих балів, посівши лише дев'яте місце.

Очікувано, що список, як і в минулі роки, очолюють країни Скандинавії, Західної Свропи, правові держави 3 розвиненою демократією. Але більшість із них в останні три роки демонструють негативну тенденцію: 15 з входять до 25 країн, які з 2016 року знижують свої показники індексу. Німеччина належить до рідкісних винятків. 
У список з 25 держав, які отримали найвищий бал за рейтингом «Трансперенсі Інтернешнл», увійшли, крім зазначених, Норвегія (84 бали), Нідерланди (82 бали), Люксембург (80 балів), Німеччина (80 балів), Ісландія (78 балів), Канада (77 балів), Великобританія (77 балів), Австралія (77 балів), Австрія (77 балів), Гонконг (76 балів), Бельгія (75 балів), Ірландія (74 бали), Естонія (74 бали), Японія (73 бали), ОАЕ (71 бал), Уругвай (71 бал), США (69 балів), Франція (69 балів), Бутан (68 балів).

Держави-члени G7 теж демонструють різкий контраст і порівняно високий рівень сприйняття корупції. У це неформальне об’єднання найбільш значущих розвинених країн світу входять - за винятком Японії - тільки західні держави. Чотири з семи погіршили свої показники порівняно з попереднім роком: Канада, Франція, Великобританія і США. «Трансперенсі Інтернешнл» вказує ще й на те, що показник США в 69 балів $є$ найгіршим за останні вісім років. Великобританія за останній час також опустилася набагато нижче: 382 балів у 2017 р. до рівня в 77 балів у 2019 р..

У кінці списку розташувалися Смен, Сирія, Південний Судан і Сомалі. 32012 р. 22 країни значно поліпшили своє становище в рейтингу корупції, серед них Естонія і Греція, Австралія і Нікарагуа.

«Трансперенсі Інтернешнл» провело дослідження на предмет зв'язку рівня корупції та політичної обстановки в країнах. Після аналізу був зроблений висновок, що в країнах із більш прозорою політичною обстановкою, активною участю представників громадськості показники індексу сприйняття корупції IBК вищі, ніж в країнах, в яких слабка залученість представників громадськості, бізнесу і політики до прийняття стратегічних, ключових політичних рішень.

У 2008 р. Німеччина потрясла світові ЗМІ найбільшим корупційним скандалом, немислимим за своїми масштабами. Компанія Siemens була звинувачена в корупційних схемах, зведених у корпоративну етику [15] .

Варто зазначити, що включення в Індекс не $є$ показником наявності корупції в країні, а залежить лише від доступності відповідних даних. Індекс сприйняття корупції - це оцінка рівня сприйняття адміністративної та політичної корупції, а не вирок про корумпованість цілих націй і спільнот. Цей показник не стосується питань, пов'язаних із міжнародною діяльністю і зовнішньою політикою, що проводиться тією чи іншою державою. Громадськість країн, що набрали найменшу кількість балів Індексу сприйняття корупції, демонструє такий самий ступінь заклопотаності проблемами протидії корупції та неприйняття iï, що і громадськість держав із вищими показниками.

Індексу сприйняття корупції властива певна доля похибки через те, що він заснований на опитуванні людей, навіть авторитетних і досвідчених. Люди намагаються бути об'єктивними, але насправді це важке для них завдання, адже об'єктивність як якість існує сама по собі і не залежить від чиєїсь оцінки i (або) особистого судження. Це така якість, яку не можна оскаржити, бо вона грунтується на постійних величинах, якими жодним чином не можна вважати опитування та експертні оцінки групи людей, що відрізняються світоглядом і особистісним сприйняттям дійсності.

Крім того, є національні особливості сприйняття людьми певних суспільних проявів, у тому числі і корупційних. Ще одна причина, з якої не вдається вивести універсальний показник, який дав би змогу порівняти держави між собою, - та обставина, що соціологи, юристи і кримінологи різних держав мають різні позиції щодо того, що являє собою корупція. Наприклад, К. Старк, Н. Кебіс і К. Брандт виділяють різні форми корупції: «велика корупція» описує корупцію на високому рівні адміністрації (наприклад, політиків), а «дрібна корупція» належить до досить поширених корупційних правопорушень (наприклад, підкуп співробітника поліції) [16]. Крім того, ще в 1979 р. Кодекс поведінки посадових осіб із підтримки правопорядку, прийнятий Генеральною Асамблеєю ООН, визначив, що саме національне право визначає, що розуміти під корупцією. Різний і перелік діянь, який законодавства країн зараховують до корупційних.

Таким чином, нині доводиться констатувати, що, на жаль, немає джерел інформації про корупцію, які задовольняли б вимогу міжкраїнної порівнянності. Індекс сприйняття корупції не може використовуватися як абсолютно точний інструмент аналізу і порівняння, бо він розраховується на базі мінливого набору джерел даних: змінювалася кількість джерел даних і країн, що включаються в індекс; 3'являлися нові опитування, а проведення деяких досліджень припинялося. Крім того, в методологію розрахунку Індексу сприйняття корупції вносилися зміни. Тому єдиним надійним способом порівняння $\epsilon$ зіставлення даних по певній державі з одного і того самого конкретного джерела протягом певного періоду часу. 


\section{Література:}

1. Лунеев В.В. Коррупция, учтенная и фактическая. Государство и право. 1996. № 8. С. 81 .

2. Монтескье Ш. Избранные сочинения. Москва, 1955. 803 с.

3. Akçay S. Corruption and human development. Cato Journal. 2006. Vol. 26. Pp. 29-48.

4. Gupta S., Davoodi H., Alonso-Terme R. Does corruption affect income inequality and poverty? Economics of governance. 2002. Vol. 3. Is. 1. Pp. 23-45.

5. Kaufmann D. Corruption and The Global Financial Crisis. URL: http://www.forbes.com/20Q9/Q1/27/corruption-financialcrisis-business-corruptionQ9 Q127corruption.html

6. Савчишкина О.Г. Индекс восприятия коррупции Транспаренси Интернешнл. Актуальные проблемы права и государства в ХХІ веке. 2015. № 7-4. С. 144-146.

7. Капитонова Н.Б., Тумаланов Н.В. Индекс восприятия коррупции - показатель уровня коррупции. Актуальные проблемы экономической теории и региональной экономики. 2014. № 3 (15). С. 51-54.

8. William De Maria. Measurements and markets: Deconstructing the corruption perception index. International Journal of Public Sector Management. 2008. Vol. 21. № 7.

9. Бухарина Н.П. Основные подходы к пониманию коррупции в международных правовых актах. Юридическая мысль. 2015. № 2. С. $72-76$.

10. Антикоррупционные организации. URL: http://www.anticorruptionday.org/actagainstcorruption/ru/resources/index.html

11. Поляков С.В. Прогнозирование изменения показателя индекса восприятия коррупции в России. Ученые записки. 2017. Т. 1, № 21. С. 5.

12. Шедий М.В. Сравнительные исследования и индикаторы распространения коррупции в современном мире. Среднерусский вестник общественных наук. 2010. № 2. С. 88-98.

13. Батищева М.А. Служебные разоблачения в сфере государственной службы. Вестник МГИМО. 2014. № 3 (36). C. $195-205$.

14. Corruption Cases Mapping Based on Indonesia's Corruption Perception Index / M. Noerlina, L. A. Wulandhari, Sasmoko, A. M. Muqsith, M. Alamsyah. Journal of Physics Conference Series. 2017. Vol. 801 (1). Pp. 012-019.

15. Уроки масштабного коррупционного скандала Siemens десятилетие спустя. URL: https://theconversation.com/lessonsfrom-the-massive-siemens-corruption-scandal-one-decadelater-108694

16. Starke C., Brandt C., Köbis N. C. The Role of social norms in corruption research. URL: https://europeanstudentthinktank.com/ 2016/01/11/therole-of-social-norms-in-corruption-research. 